\title{
Modern accumulation rates and a budget of sediment off the Gaoping (Kaoping) River, SW Taiwan: A tidal and flood dominated depositional environment around a submarine canyon
}

\author{
Chih-An Huh ${ }^{\mathrm{a}, *}$, Hui-Ling Lin ${ }^{\mathrm{b}}$, Saulwood Lin ${ }^{\mathrm{c}}$, Ya-Wen Huang ${ }^{\mathrm{a}}$ \\ a Institute of Earth Sciences, Academia Sinica, Taipei, Taiwan, ROC \\ b Institute of Marine Geology and Chemistry, National Sun Yat-Sen University, Kaohsiung, Taiwan, ROC

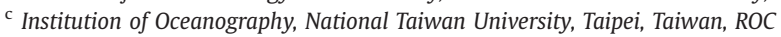

\section{A R T I C L E I N F O}

\section{Article history:}

Received 3 January 2007

Received in revised form 27 July 2007

Accepted 27 July 2007

Available online 26 August 2008

\section{Keywords:}

Sedimentation

Gaoping River

Submarine canyon

${ }^{210} \mathrm{~Pb}$

${ }^{137} \mathrm{Cs}$

${ }^{7} \mathrm{Be}$

\begin{abstract}
A B S T R A C T
Ninety-two box cores collected during 2004-2006 from an area of $\sim 3000 \mathrm{~km}^{2}$ off the Gaoping (formerly spelled Kaoping) River, SW Taiwan, were analyzed for fallout radionuclides $\left({ }^{210} \mathrm{~Pb}\right.$,

${ }^{137} \mathrm{Cs}$ and ${ }^{7} \mathrm{Be}$ ) to elucidate sedimentation rates and processes, and for the calculation of a sediment budget. The study area is located at an active collision margin with a narrow shelf and a submarine canyon extending essentially into the river's mouth. The results indicate fairly constant hemipelagic sedimentation in much of the open margin and for most of the time except in the inner shelf and along the axis of the canyon where sediment transport is more dynamic and is controlled by tidal current and wave activities constantly, and by fluvial floods or gravity-driven flows episodically. Sedimentation rates in the study area derived from ${ }^{210} \mathrm{~Pb}$ and constrained by ${ }^{137} \mathrm{Cs}$ vary from 0.04 to $1.5 \mathrm{~cm} / \mathrm{yr}$, with the highest rates $(>1 \mathrm{~cm} / \mathrm{yr}$ ) flanking the Gaoping canyon over the upper slope $(200-600 \mathrm{~m})$ and the lowest rates $(<0.1 \mathrm{~cm} / \mathrm{yr})$ in the distal basin beyond the continental slope. The depocenter delineated from ${ }^{210} \mathrm{~Pb}$-based sedimentation rates overlaps with the area covered by a flood layer resulting from supertyphoon Haitang in July 2005. Such correspondence supports the notion that the processes operating on event timescale have bearing on the formation of the sediment strata over centennial or longer timescales.

From the distribution of sedimentation rates, sediment deposited in the study area annually is estimated to be 6.6 Mton/yr, accounting for less than $20 \%$ of Gaoping River's sediment load. The calculated budget, coupled with the presence of the short-lived ${ }^{7} \mathrm{Be}$ and non-steady-state distribution of low levels of ${ }^{210} \mathrm{~Pb}$ in sediments along the canyon floor, suggests rapid transport of sediment from Gaoping River's mountainous watershed (the source) via the Gaoping (Kaoping) Submarine Canyon and adjacent channels (as the conduit and temporary sink) to the abyssal plain and the Manila Trench in the South China Sea (the ultimate sink).
\end{abstract}

(c) 2008 Elsevier B.V. All rights reserved.

\section{Introduction}

The Gaoping (formerly spelled Kaoping) River (KPR) is the second longest river in Taiwan whose main stem meanders $171 \mathrm{~km}$ through a highly rugged terrain in the Central Mountain

\footnotetext{
* Corresponding author. Tel.: +886 22783 9910; fax: +886 227839871.

E-mail address: huh@earth.sinica.edu.tw (C.-A. Huh).
}

Range, from the Jade Mountain (Yushan) at an elevation over $3000 \mathrm{~m}$ toward the southwest, creating the largest drainage basin $\left(3257 \mathrm{~km}^{2}\right)$ in Taiwan (Fig. 1). Climate in the KPR drainage basin is tropical to sub-tropical and influenced by typhoons and the annual monsoon cycle. Mean annual rainfall in the KPR drainage basin is $3046 \mathrm{~mm}$, which sustains an annual river discharge of $8.5 \times 10^{9} \mathrm{~m}^{3}$. More than $70 \%$ of the basin's annual rainfall and river discharge occurs during May-September, and is closely linked with the occurrence of typhoons. Highly 

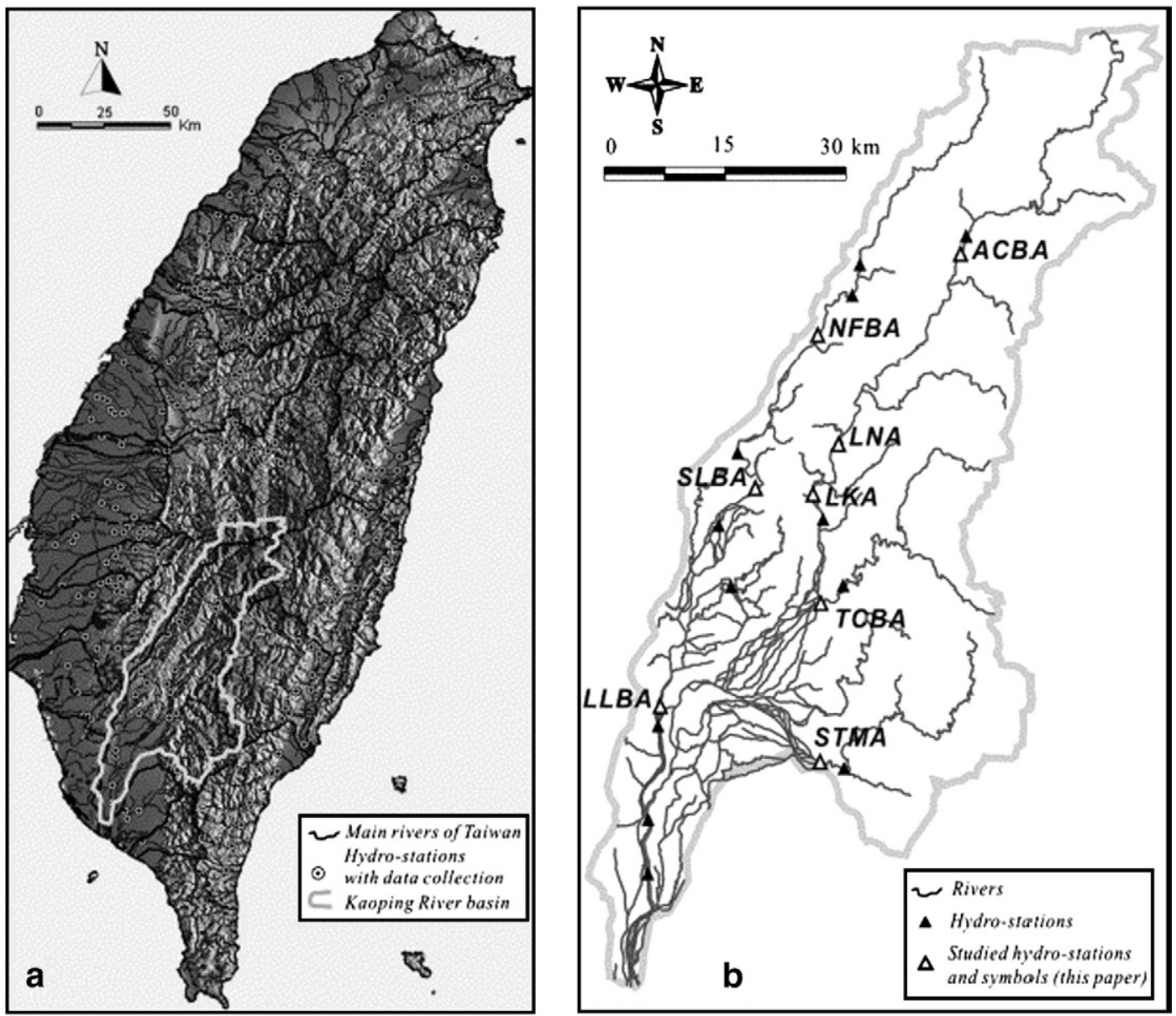

Fig. 1. (a) Gaoping River's drainage basin in southwestern Taiwan. (b) Tributaries and hydrological gauging stations in the basin (after Li et al., 2005, with permission from Elsevier).

erodible sedimentary and metamorphic rocks in the drainage basin, coupled with a steep landscape, humid climate, frequent typhoons and earthquakes, provide favorable conditions for bedrock weathering and soil erosion in the KPR drainage basin. Consequently, during periods of high flow, the river water is rather turbid.

Sediment load of the KPR is reported to range from $36 \mathrm{Mton} /$ yr (Water Resources Bureau, 1998; Milliman and Kao, 2005) to $49 \mathrm{Mton} / \mathrm{yr}$ (Dadson et al., 2003), which is among the top three of Taiwan's rivers and gives rise to a sediment yield of $1.5 \times 10^{4}$ ton $\mathrm{km}^{-2} \mathrm{yr}^{-1}$ in the KPR basin. Although this sediment yield ranks only fourth among Taiwan's major watersheds, it is still about an order of magnitude higher than similar high-yield rivers such as the Eel River in Northern California $\left(1.7 \times 10^{3}\right.$ ton $\mathrm{km}^{-2} \mathrm{yr}^{-1}$; highest in the conterminous United States; Brown and Ritter, 1971) and the Sepik River in New Guinea (1.1$1.3 \times 10^{3}$ ton $\mathrm{km}^{-2} \mathrm{yr}^{-1}$, Chappell, 1993; Syvitski and Morehead, 1999; Walsh and Nittrouer, 2003).

Like the Eel and Sepik rivers, the KPR is a mountainous river located at an active margin with a submarine canyon near its mouth traversing a narrow shelf. It has been increasingly recognized that such rivers play an important role in transporting terrigenous materials from land to sea and are likely representative of conditions during the Pleistocene. Lowered sea level at that time exposed many of the world's shelves, and rivers delivered their sediment load directly to the continental slope and beyond (Milliman, 1995; Woolfe et al., 1998). Although the KPR is much smaller (in length and drainage basin area) compared with the Eel and Sepik rivers, its exceptionally high sediment yield and tidal-dominated dispersal system presents a unique case for comparative study.

During the FATES-KP program, the shelf and slope areas around the Gaoping Submarine Canyon (KPSC) off the KPR were extensively surveyed and sampled. As a component of FATES$\mathrm{KP}$, we have analyzed almost all sediment cores collected for the program since 2004 for ${ }^{210} \mathrm{~Pb},{ }^{137} \mathrm{Cs}$ and ${ }^{7} \mathrm{Be}$. Using these fallout radionuclides as time and process tracers, our objective is to elucidate rates, budget and dispersal pathways of sediment in the study area.

\section{Materials and methods}

\subsection{The study area}

To facilitate this study, we delimited a rectangle-shaped domain of $\sim 3000 \mathrm{~km}^{2}$ centered offshore of the KPR mouth that 
encompasses the upper KPSC ( $<2000 \mathrm{~m}$ depth $)$ and its adjacent shelf and slope (Fig. 2). The KPR is inferred to be the dominant source of terrigenous sediment delivered to the area, given the river's high discharge (the second largest in Taiwan), the proximity $(\sim 1 \mathrm{~km})$ of its river mouth to the head of KPSC (Liu et al., 2002), and local seafloor morphology. Smaller discharges from other rivers draining southwestern Taiwan and littoral drift are probably intercepted by and trapped in the neighboring canyons and channels (Lewis and Barnes, 1999), hence insignificant in the study area. Thus, the study area represents a fairly well defined system around the KPSC for assessing source-to-sink sediment dispersal and the calculation of sediment budgets. For more details about the seafloor morphology and its implications on geotectonics and sediment dispersal, please refer to Yu et al. (2009-this issue).

\subsection{Sampling}

A total of 92 box cores were collected onboard R/V Ocean Researcher-I (OR1) and R/V Ocean Researcher-III (OR3) from eight cruises during 2004-2006, including OR3-1075 (September 30, 2004), OR1-732 (September 30-October 4, 2004), OR1761 (August 2-3, 2005), OR1-779 (December 18-21, 2005), OR1-789 (March 29-April 2, 2006), OR1-791 (April 11-15, 2006), OR1-803 (August 5-9, 2006) and OR1-811 (October 11$15,2006)$. Fig. 3 shows the location of sampling sites. Some reference stations were occupied on two or more cruises to follow the evolution of a flood layer as it was gradually buried during the two-year study period.
After the overlying water was siphoned from the box corer, core barrels were used to collect subcores for lab analyses. Sediments in the subcores were immediately extruded and sectioned at $2-\mathrm{cm}$ intervals from the top. The sectioned sediment slices were sealed in plastic bags and kept frozen until being freeze-dried in the laboratory. Based on weight loss after freeze-drying, water content (hence, porosity) of the wet sediments was determined. Dried samples were then transferred to plastic jars (i.d., $8.5 \mathrm{~cm}$; height, $7.5 \mathrm{~cm}$ ) for nondestructive gamma spectrometric assay of radionuclides of interest followed by destructive chemical analyses for other studies performed by the FATES-KP team. The data reported in this paper are calculated on a salt-free dry-weight basis.

\subsection{Gamma spectrometry}

Four radionuclides $\left({ }^{210} \mathrm{~Pb},{ }^{137} \mathrm{Cs},{ }^{7} \mathrm{Be}\right.$ and $\left.{ }^{214} \mathrm{~Pb}\right)$ were analyzed, all by the non-destructive gamma spectrometry. ${ }^{210} \mathrm{~Pb}$ and ${ }^{137} \mathrm{Cs}$ are used as sediment chronometers while ${ }^{7} \mathrm{Be}$ is used to trace flood sedimentation. ${ }^{214} \mathrm{~Pb}$, a precursor of ${ }^{210} \mathrm{~Pb}$, is used as an index of supported ${ }^{210} \mathrm{~Pb}$. It is necessary to subtract supported ${ }^{210} \mathrm{~Pb}$ from the measured ${ }^{210} \mathrm{~Pb}$ in order to obtain unsupported ${ }^{210} \mathrm{~Pb}$ (also called excess ${ }^{210} \mathrm{~Pb}$ ).

Five HPGe detectors were used in this study: one 150\% efficiency (relative to $3 \times 3 \mathrm{NaI}$ ) detector (EG\&G ORTEC GEM150230), three 100\% efficiency detectors (EG\&G ORTEC GMX100230) and one Lo-AX detector (EG\&G ORTEC Lo-AX-100230), each interfaced to a digital gamma-ray spectrometer (DSPec Plus $\left.{ }^{\circledR}\right)$. All detectors were calibrated using IAEA standards 133A,

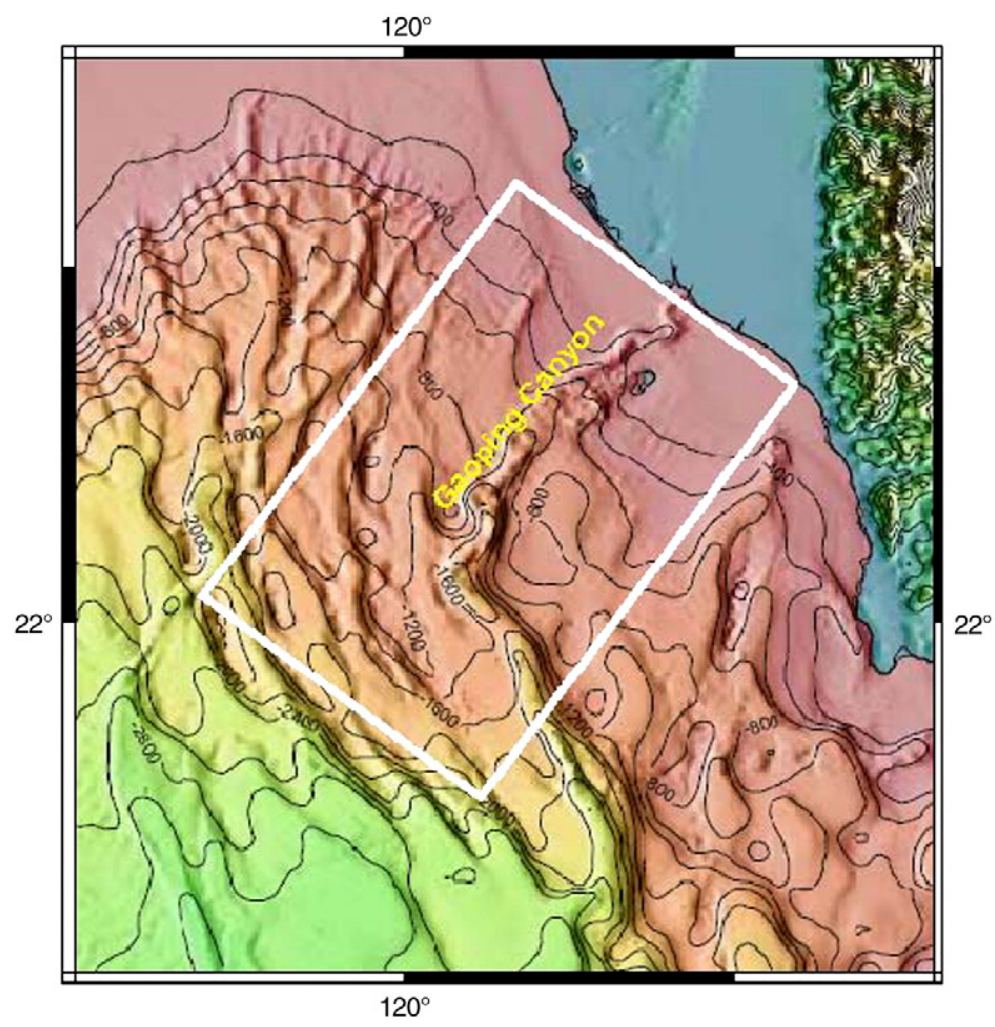

Fig. 2. Map showing the bathymetry off the Gaoping River's mouth around the Gaoping Canyon. The rectangle marks the area covered in this study. 


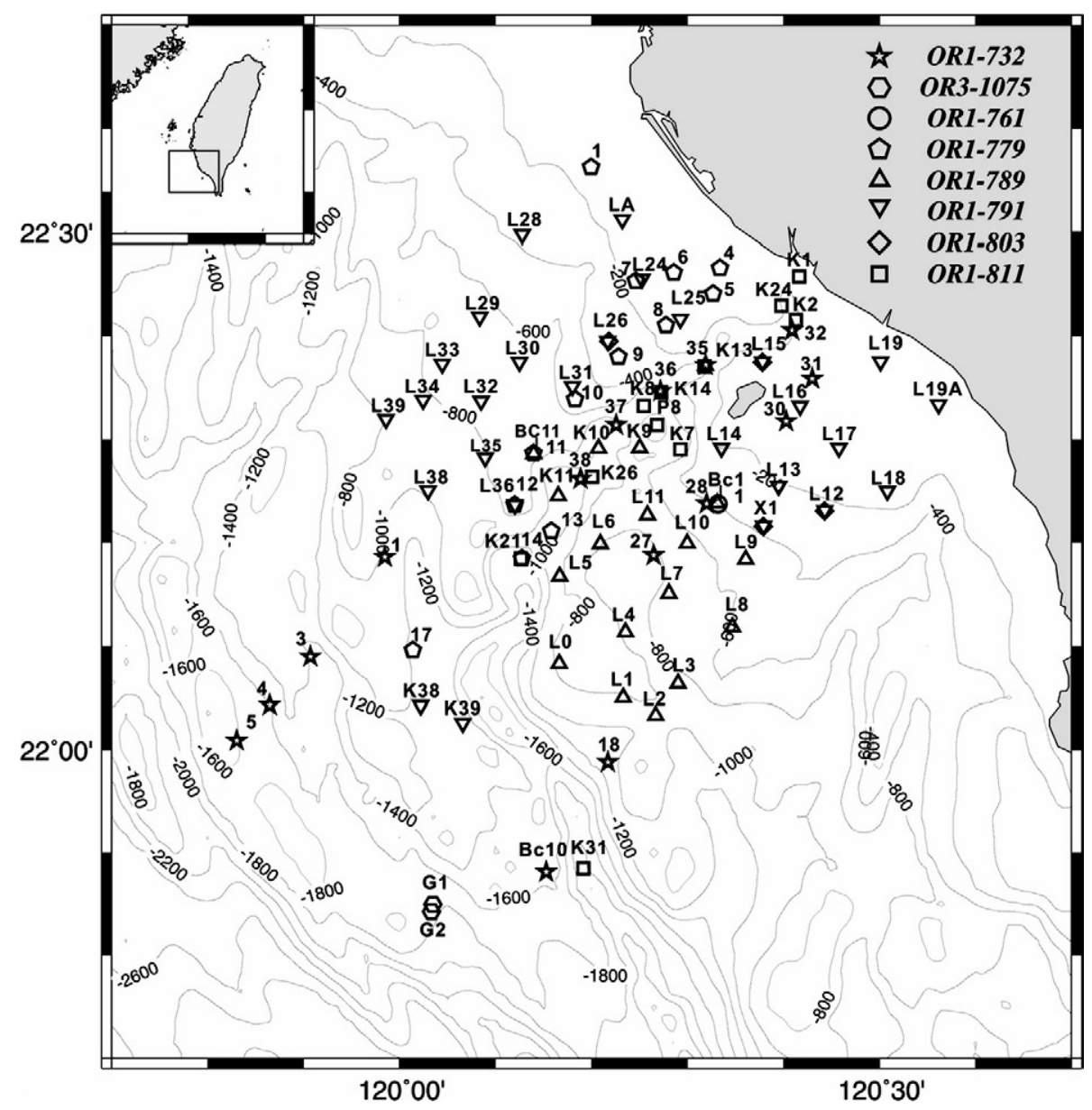

Fig. 3. Map showing sampling sites. Coring sites in different cruises are denoted by different symbols. The numbers marked by the coring sites represent box core numbers. The data for all studied cores are archived at: http://dmc.earth.sinica.edu.tw/Contributor/Huh/Huh_et_al2007a/.

327 and 375 for sample weight at $100 \mathrm{~g}$ as a reference, coupled with an in-house working standard for various masses from $10 \mathrm{~g}$ to $250 \mathrm{~g}$.

Among the three types of HPGe detectors, the GEM detector has higher efficiencies for counting high-energy gammas, including those of ${ }^{214} \mathrm{~Pb}(351.99 \mathrm{keV}),{ }^{7} \mathrm{Be}(477.56 \mathrm{keV})$ and ${ }^{137} \mathrm{Cs}(661.62 \mathrm{keV})$, whereas the Lo-AX detector has the best resolution and efficiency for counting low-energy gammas such as that of ${ }^{210} \mathrm{~Pb}(46.52 \mathrm{keV})$. As for the GMX detectors, they are capable of counting both high and low-energy gammas, although they are less effective than the Lo-AX detector for counting ${ }^{210} \mathrm{~Pb}$ and less efficient than the GEM detector for counting ${ }^{214} \mathrm{~Pb},{ }^{7} \mathrm{Be}$ and ${ }^{137} \mathrm{Cs}$. When the measurements of ${ }^{7} \mathrm{Be}$ and ${ }^{137} \mathrm{Cs}$ are critical, the GEM is the detector of choice. In that case, it is necessary to engage a combined use of the GEM and Lo-AX detectors to yield the best dataset.

\section{Results and discussion}

The full dataset generated from the 92 cores are too massive to be fully presented in this paper, and thus the following figures prepared from the dataset are used to illustrate salient features and highlight the major points. The dataset is archived in its entirety at the website: http://dmc.earth.sinica.edu.tw/ Contributor/Huh/Huh_et_al2007a/.

\subsection{Sedimentation rates}

Owing to its constant production, ubiquitous distribution and ease of measurement, ${ }^{210} \mathrm{~Pb}$ is the most commonly used chronometer for the determination of modern sedimentation rates in continental margin environments. In most of cores from the study area, except those from the inner shelf and canyon floor, profiles of excess ${ }^{210} \mathrm{~Pb}\left({ }^{210} \mathrm{~Pb}_{\mathrm{ex}}={ }^{210} \mathrm{~Pb}-{ }^{214} \mathrm{~Pb}\right)$ show exponential or quasi-exponential decreases with depth. Such profiles are customarily interpreted by a steady-state advection-decay model assuming that fluxes of sediment and ${ }^{210} \mathrm{~Pb}$ at a given site are constant, with the influx of ${ }^{210} \mathrm{~Pb}_{\mathrm{ex}}$ by precipitation at the sediment-water interface balanced by radioactive decay following burial. The distribution of excess ${ }^{210} \mathrm{~Pb}$ downcore is thus invariable with time and can be described by: $\left.\left.{ }^{210} \mathrm{~Pb}_{\mathrm{ex}}\right)_{z}={ }^{210} \mathrm{~Pb}_{\mathrm{ex}}\right)_{0} \exp (-\lambda / S)$, where $\left.{ }^{210} \mathrm{~Pb}_{\mathrm{ex}}\right)_{0}$ and $\left.{ }^{210} \mathrm{~Pb}_{\text {ex }}\right)_{z}$ are excess ${ }^{210} \mathrm{~Pb}$ at the sediment-water interface and depth $Z$, respectively, $\lambda$ is the decay constant of ${ }^{210} \mathrm{~Pb}$ and $S$ is the sedimentation rate. From the slope of the regression line $(-\lambda / S)$ fitting the depth trend of ${ }^{210} \mathrm{~Pb}_{\mathrm{ex}}$ on a semi-log plot 
(i.e., $\ln { }^{210} \mathrm{~Pb}_{\mathrm{ex}}$ versus apparent depth in $\mathrm{cm}$ or cumulative mass in $\mathrm{g} \mathrm{cm}^{-2}$ ), $S$ (linear sedimentation rate in $\mathrm{cm} \mathrm{yr}^{-1}$ or mass accumulation rate in $\mathrm{g} \mathrm{cm}^{-2} \mathrm{yr}^{-1}$ ) can be derived. Some representative profiles of ${ }^{210} \mathrm{~Pb}_{\mathrm{ex}}$ and sedimentation rates thus estimated are shown in Fig. 4.

Although ${ }^{137} \mathrm{Cs}$ can be measured along with ${ }^{210} \mathrm{~Pb}$ by gamma spectrometry, it is time-consuming to obtain ${ }^{137} \mathrm{Cs}$ data owing to its much lower activities. Thus, this anthropogenic nuclide is analyzed only for selected cores to help constrain ${ }^{210} \mathrm{~Pb}$ chronology. ${ }^{137} \mathrm{Cs}$ commonly displays a subsurface activity maximum, from which activity usually decreases gradually upward but sharply downward, reflecting the history of production, cycling and removal of this anthropogenic nuclide in the Earth's surface environments. In this study, ${ }^{210} \mathrm{~Pb}$-based sedimentation rates agree reasonably well with those estimated from the depth of the subsurface ${ }^{137} \mathrm{Cs}$ peak (marking 1963A.D.) or the penetration depth of ${ }^{137} \mathrm{Cs}$ (circa 1950A.D.). This suggests that, in this study, sediment profiles of particlereactive nuclides such as ${ }^{210} \mathrm{~Pb}$ and ${ }^{137} \mathrm{Cs}$ are controlled primarily by syndepositional sedimentation and that the impact of post-depositional processes on calculated sedimentation rates is less important.

Integrating radionuclide results over the study area reveals the spatial distribution of sedimentation rates (Fig. 5). The most striking feature revealed is a pair of depositional lobes with sedimentation rates $>1 \mathrm{~cm} / \mathrm{yr}$ that flank the KPSC along the upper slope (200-600 m). This depocenter may be caused by

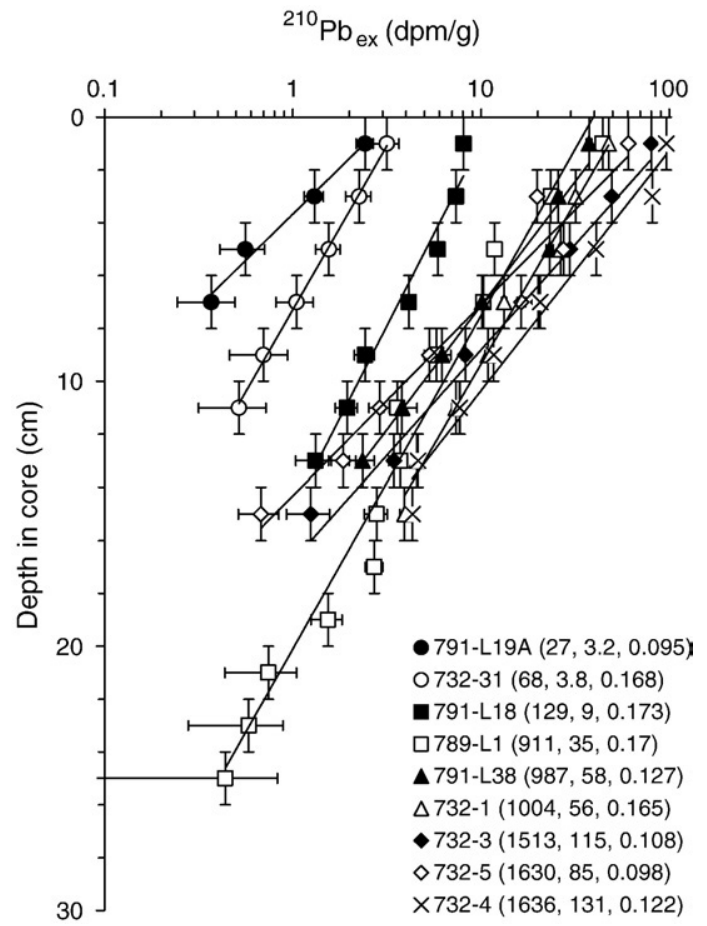

Fig. 4. Profiles of ${ }^{210} \mathrm{~Pb}_{\mathrm{ex}}$ in the open margin away from the Gaoping canyon and the flood-affected area depicted in Fig. 7 commonly show good fit (with $R^{2}>0.95$ ) to a steady-state sedimentation-decay model, with core-top ${ }^{210} \mathrm{~Pb}_{\mathrm{ex}}$ activity $\left(C_{0}\right)$ generally increasing with water depth $(Z)$ (please also refer to Fig. 6). Following the cruise/core numbers in the legend are $Z(\mathrm{~m})$ and best-fit values of $C_{\mathrm{o}}(\mathrm{dpm} / \mathrm{g})$ and $S(\mathrm{~cm} / \mathrm{yr})$ corresponding to each profile. sedimentation from turbidity flows overflowing the canyon. It is noteworthy that the depositional lobe is centered along the canyon axis at a locale where the channel turns and widens abruptly, with some topographic highs protruding the channel floor. We suspect that such a topographic setting may dissipate the energy of fluvial plumes or turbidity flows, thus facilitating over-bank levee sedimentation.

From the aforementioned depocenter, sedimentation rates generally decrease toward the base of the slope and basin floor where pelagic or hemipelagic sedimentation of fine-grained (silty and clayey) sediment results in the area's lowest sedimentation rates $(<0.1 \mathrm{~cm} / \mathrm{yr}$ ). Low sedimentation rates (or no net accumulation of sediments) were also observed on the inner shelf covered primarily by reworked sands. Although the muddy component of fluvial sediment can accumulate ephemerally nearshore during or shortly following floods, over longer timescales it cannot withstand strong shear generated by tidal currents and wave activity and is preferentially transported down the canyon and offshore (Liu et al., 2002; Crockett and Nittrouer, 2004).

\subsection{A differentiation of sedimentation regimes by core-top ${ }^{210} \mathrm{~Pb} b_{e x}$ versus water depth}

In theory, specific activities of excess ${ }^{210} \mathrm{~Pb}$ in sediment particles are controlled primarily by particle size, residence time of particles in the water column, atmospheric flux and water-column production rate of ${ }^{210} \mathrm{~Pb}$. In general, sizes of sediment particles decrease, while their residence times in seawater increase, with distance offshore and resulting greater water depths. Thus, it is reasonable to expect higher excess ${ }^{210} \mathrm{~Pb}$ activities in fine sediments freshly deposited in deep waters under steady-state conditions. Any deviations from this general rule may be largely ascribed to non-steadystate conditions.

By plotting ${ }^{210} \mathrm{~Pb}_{\mathrm{ex}}$ activity at core top versus water depth (Fig. 6) and from the spatial distribution of core-top ${ }^{210} \mathrm{~Pb}_{\mathrm{ex}}$ (Fig. 7), we can differentiate two sedimentation regimes. In Fig. 6, data points from the open shelf and slope area outside the canyon (open circles) follow a linear increase with depth, reflecting continuous scavenging of ${ }^{210} \mathrm{~Pb}$ from seawater as particles work their way down the water column slowly. In contrast most samples from the canyon floor or its vicinity with steep topography (closed circles) show anomalously low ${ }^{210} \mathrm{~Pb}_{\text {ex }}$ activities (Fig. 7), which may be explained by postdepositional disturbances such as slumping, scouring, or rapid down-canyon transport and deposition of fresh fluvial or old reworked shelf sediments low in excess ${ }^{210} \mathrm{~Pb}$. The data imply that, on ${ }^{210} \mathrm{~Pb}$ timescale ( $\sim 100$ years), the KPSC is not a steady setting for ${ }^{210} \mathrm{~Pb}$ scavenging and sediment accumulation; rather, it is mainly at a transient state, with intermittent sediment transportation.

\subsection{A flood layer deposited during typhoon Haitang in July $2005-$ its spatial distribution and implications}

During July 11-12, 2005, typhoon Haitang developed in the western Pacific, about $3500 \mathrm{~km}$ to the east of Taiwan. As Haitang proceeded toward the west, it intensified, reaching the highest category on July 16 and making landfall at eastern Taiwan on July 18 . In the ensuing days, the typhoon caused unprecedented 


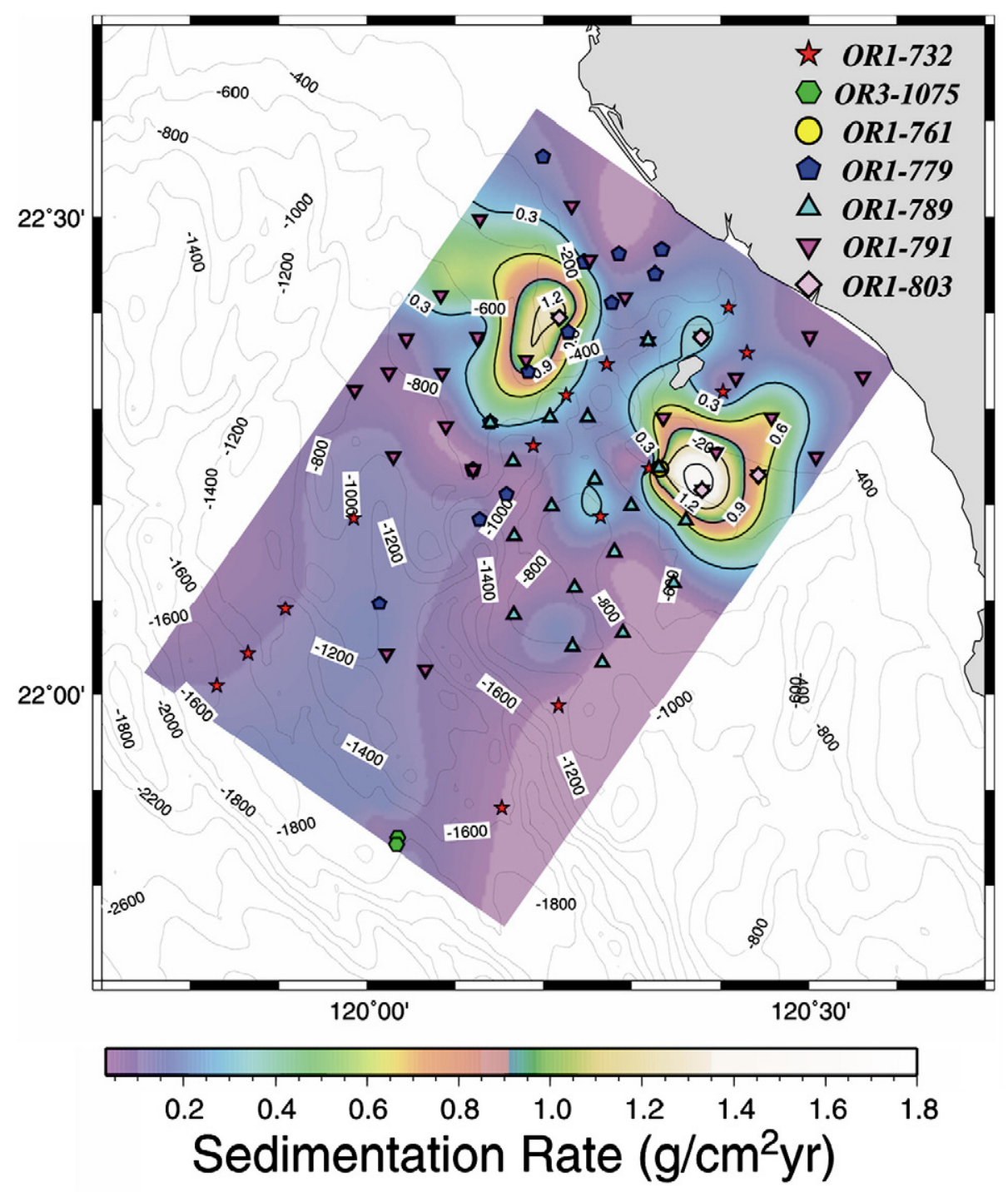

Fig. 5. Contour map showing spatial distribution of ${ }^{210} \mathrm{~Pb}$-based sedimentation rates.

rainfall in KPR's drainage basin. Near the river's headwater at Alishan, for example, daily rainfall reached $663 \mathrm{~mm}$ on July 19 , 2005, with a 3-day cumulative rainfall of $1226 \mathrm{~mm}$ during July 18-20, 2005. Rainfall so intense would conceivably bring about high river discharge and high sediment load. On August 2, 2005, two weeks following Haitang, a box core was collected on the OR1-761 cruise (OR1-761 BC1) from a depth of $389 \mathrm{~m}$ on the upper slope. A freshly deposited flood layer about $4 \mathrm{~cm}$ thick was identified at the core top. This layer is characterized by anomalously low ${ }^{210} \mathrm{~Pb}$ and appreciable ${ }^{7} \mathrm{Be}(\sim 1 \mathrm{dpm} / \mathrm{g})$. Below this layer, ${ }^{210} \mathrm{~Pb}_{\mathrm{ex}}$ decreases exponentially with depth from a rather high activity while the deposition record of ${ }^{137} \mathrm{Cs}$ reflects the history of nuclear fallout very well, with a subsurface maximum located at 34-36 cm (see Fig. 9a). Both ${ }^{210} \mathrm{~Pb}_{\mathrm{ex}}$ and ${ }^{137} \mathrm{Cs}$ profiles point to an average sedimentation rate of $0.77 \mathrm{~cm}$ $\mathrm{yr}^{-1}$ at least in the past four decades prior to the deposition of the flood layer induced by typhoon Haitang.
The flood deposit, first discovered on the OR1-761 cruise, was observed in all subsequent cruises and its distribution mapped (Fig. 8). It is important to note that the area covered by this event layer corresponds closely to the depositional lobe delineated from ${ }^{210} \mathrm{~Pb}$. In fact, similar correspondence was documented previously for a flood dominated continental shelf off Eel River's mouth in Northern California, suggesting that the processes creating event layers may be relevant to the formation of the sediment strata over time scales of 100 years or longer (Sommerfield and Nittrouer, 1999; Bentley and Nittrouer, 2003).

Besides the data for OR1-761 BC1, Fig. 9 shows two more sets of ${ }^{210} \mathrm{~Pb}_{\mathrm{ex}}$ and ${ }^{137} \mathrm{Cs}$ profiles in the flood-affected area. From the depletion of ${ }^{210} \mathrm{~Pb}$ near core top, the thickness of the flood layer is estimated to vary between 2 and $12 \mathrm{~cm}$. Where the flood layer is thicker (e.g., in OR1-789 BC11; see Fig. 9b), it appears that this event contained two separate episodes which can be correlated 


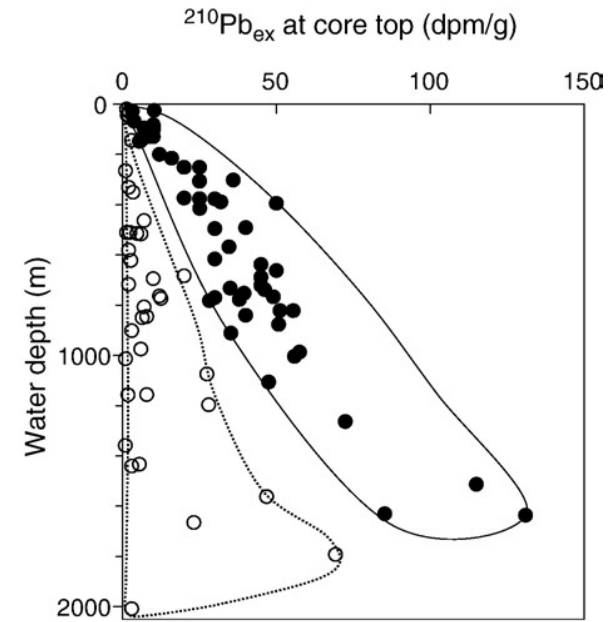

Fig. 6. Plot of core-top ${ }^{210} \mathrm{~Pb}_{\mathrm{ex}}$ versus water depth from which two sedimentation regimes are outlined, solid circles represent cores from the open shelf and slope showing fairly steady sedimentation whereas open circles represent cores from the canyon floor or walls showing non-steady-state ${ }^{210} \mathrm{~Pb}_{\mathrm{ex}}$ profiles. See text for explanation. among some adjacent cores. By comparing downcore distribution of ${ }^{210} \mathrm{~Pb}$ observed at different times, it can be noted that the flood material, represented by a ${ }^{210} \mathrm{~Pb}$ minimum near core top (Fig. 9a), was gradually buried by and mixed with hemipelagic sediment deposited following the flood (Fig. 9c). In summary, this flood deposit is manifested in the ${ }^{210} \mathrm{~Pb}_{\text {ex }}$ profiles as a dramatic event of perhaps 100-year recurrence. Given the deposit's thickness and high sedimentation rates in the depocenter, the flood layer is unlikely to be completely eroded by post-depositional processes. In fact, in addition to the most recent flood deposit found at core top, there appears to be some indication of buried flood layers or mixed layers in some cores (e.g., 779-9, 791-L31, 791-L24, 791-L17, 791-L13) around the depocenter.

\subsection{Recent down-canyon transport of fluvial sediments elucidated} from ${ }^{7} \mathrm{Be}$ and ${ }^{210} \mathrm{~Pb}$

To understand sediment transport pathways along the KPSC, the last two cruises for this study (OR1-803 and 811) focused on surveying the thalweg of the canyon. In the hope of finding a flood deposit and following its evolution, the

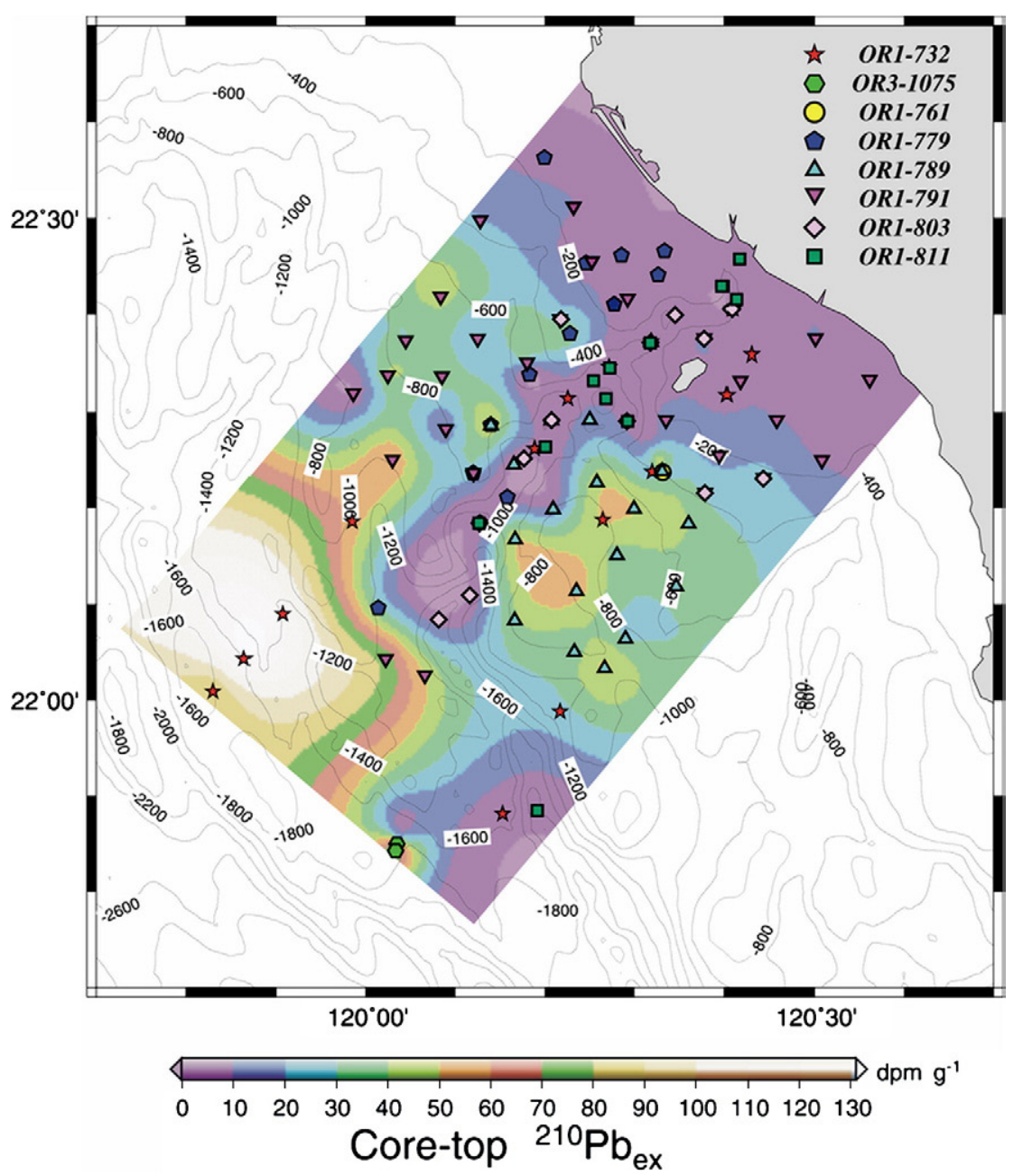

Fig. 7. Spatial distribution of core-top ${ }^{210} \mathrm{~Pb}_{\mathrm{ex}}$ shows low values along the axis of Gaoping canyon. 


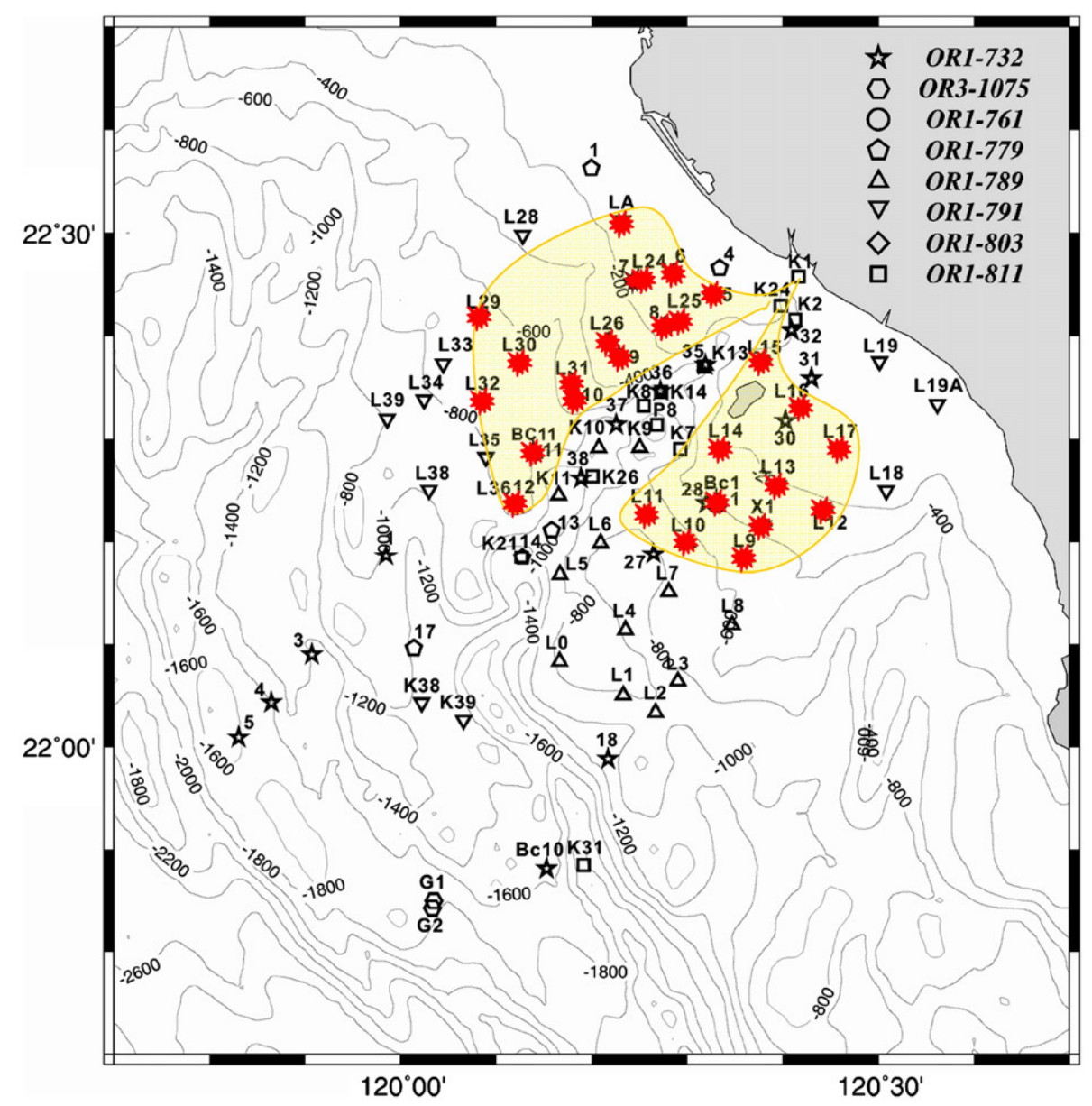

Fig. 8. Distribution of the flood layer deposited following typhoon Haitang (July 18-20, 2005). The red explosion sign indicates sighting of this event deposit in cores collected since August 2005.

cruises were conducted during the typhoon season of 2006 following typhoons Bilis (July 11-17, 2006) and Kaemi (July 24-27, 2006) which had affected the study area. Special attention was made to measure the short-lived ${ }^{7} \mathrm{Be}$, a useful tracer for flood sedimentation in coastal zones (Sommerfield et al., 1999; Mullenbach et al., 2004; Moralles et al., 2006). ${ }^{7} \mathrm{Be}$ was found widely in surficial sediments from the upper reaches of the canyon, with generally higher activities in samples from the OR1-811 cruise (October 11-15, 2006) compared with those from OR1-803 (August 5-9, 2006). Since there were no floods between these two cruises, the temporal variation could be attributed to sufficiently long watercolumn residence times (of one to several months) for suspended fluvial particles. Indeed, during the OR1-803 cruise SPM concentrations along the canyon were substan- tially higher than those measured during the OR1-811 cruise, suggesting that much of the suspended fluvial sediments discharged in July were deposited after August 2006.

In addition to temporal variability, spatial patterns in ${ }^{7} \mathrm{Be}$ activity also reveal higher levels near the river mouth, with the highest ${ }^{7} \mathrm{Be}$ activity of $\sim 1 \mathrm{dpm} / \mathrm{g}$ observed near the canyon head (site K1) during the OR1-811 cruise. In addition to the high activity measured at the sediment surface, ${ }^{7} \mathrm{Be}$ was measured to a depth of $12 \mathrm{~cm}$ in core OR1-811 $\mathrm{K} 1$, with a large inventory of $7.8 \pm 0.4 \mathrm{dpm} \mathrm{cm}^{-2}$ (Fig. 10 inset). At sites further offshore of the river mouth, ${ }^{7} \mathrm{Be}$ was detectable only in the top layer $(0-2 \mathrm{~cm})$. As discussed earlier, it is highly likely that the ${ }^{7} \mathrm{Be}$-enriched sediment layer was formed by gradual removal (in 2-3 months) of fluvial SPM introduced by typhoons Bilis and Kaemi in July 2006.

Fig. 9. Examples of ${ }^{210} \mathrm{~Pb}_{\mathrm{ex}}$ and ${ }^{137} \mathrm{Cs}$ profiles in cores collected at different time and location from the flood area outlined in Fig. 6. Shown here are (a) in the top row: a sharp depletion of ${ }^{210} \mathrm{~Pb}$ in the flood layer deposited at the site of OR1-761 BC1 two weeks following Haitang, (b) in the middle row: a thick (>10 cm) flood layer in core OR1-789 BC11 suggesting two episodes in the event, and (c) in the bottom row: gradual burial of the flood layer in core OR1-791 L29 by hemipelagic sediment deposited following the event. 

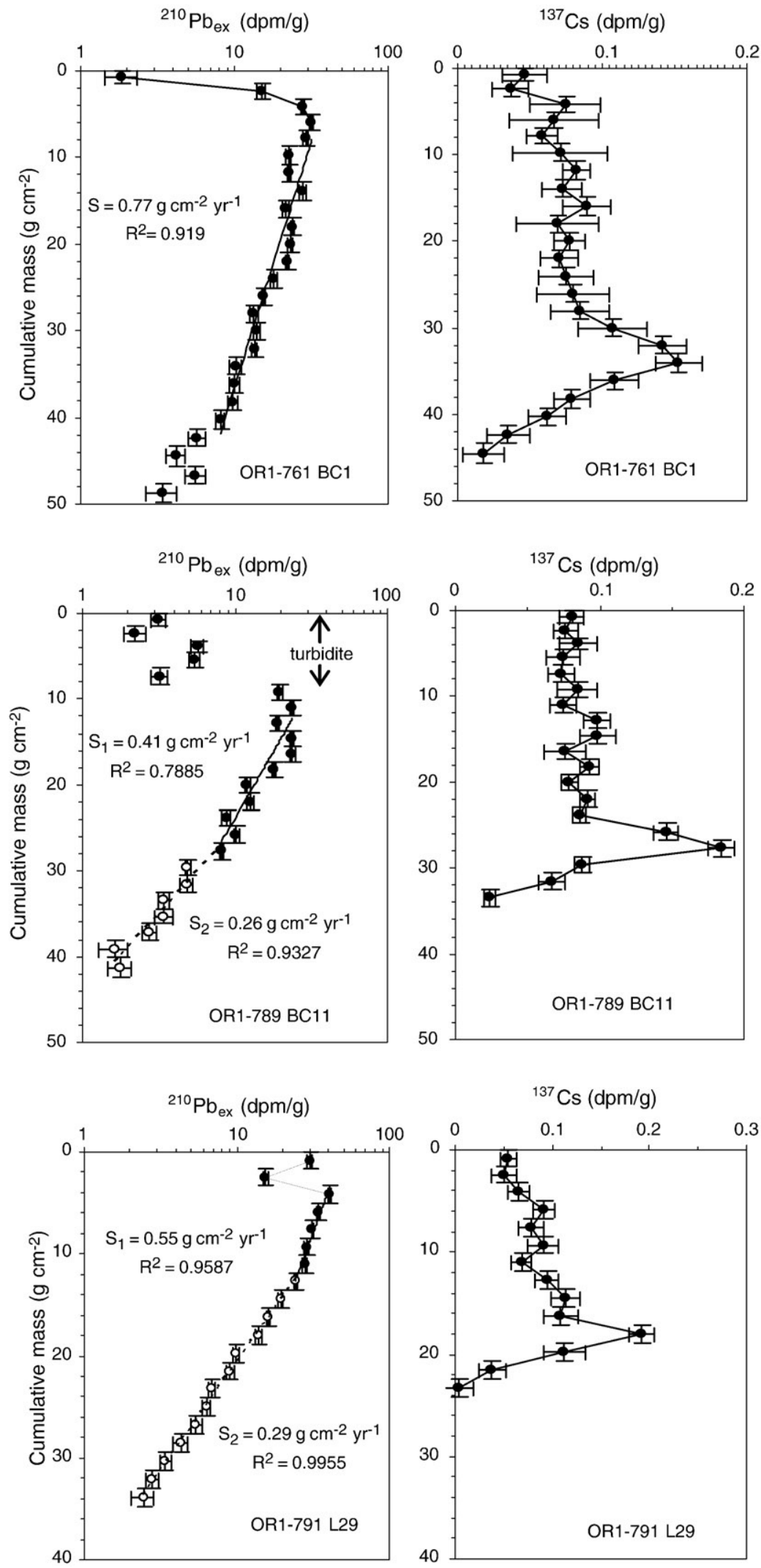


\section{${ }^{7} \mathrm{Be}(\mathrm{dpm} / \mathrm{g})$}

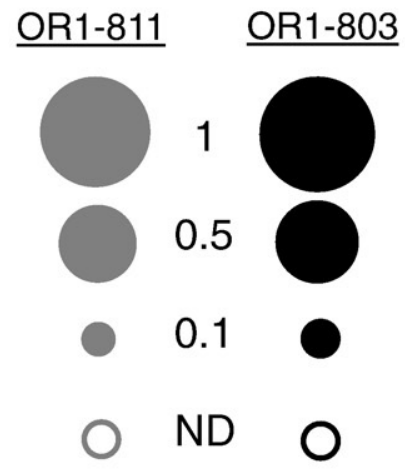

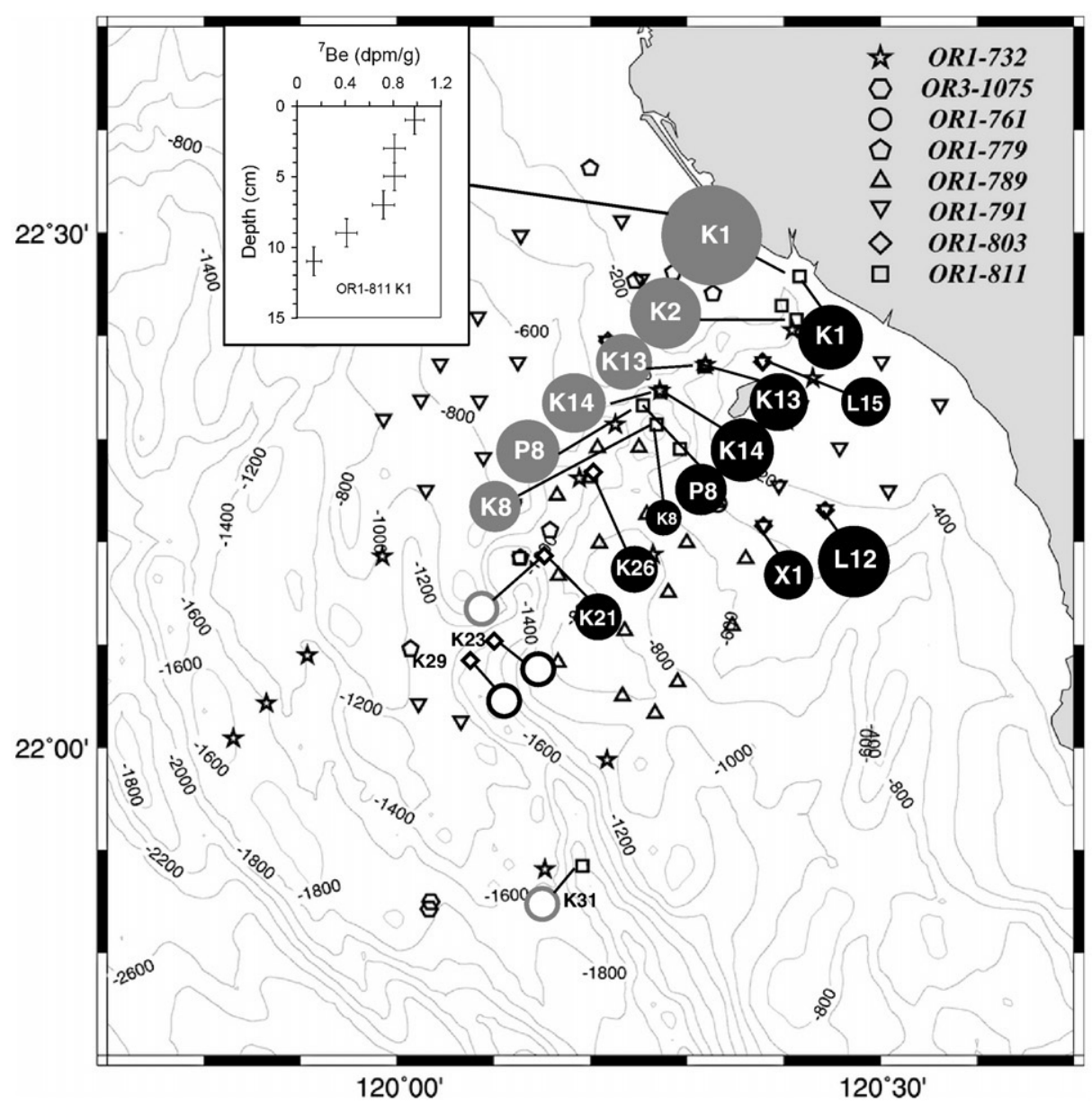

Fig. 10. Activities of ${ }^{7} \mathrm{Be}$ in surficial sediments along the thalweg of the KPSC during the OR1-803 cruise (August 5-9, 2006; black circles) and the OR1-811 cruise (October 11-15, 2006; gray circles). Empty circles indicate ${ }^{7} \mathrm{Be}$ not detectable (N.D.). The plot in the upper inset shows that ${ }^{7} \mathrm{Be}$ can be detected down to $12 \mathrm{~cm}$ in core OR1-811 K1 near the head of the Gaoping Canyon.

Besides sampling along the canyon during the OR1-803 cruise, three previously (on OR1-791) occupied sites outside the canyon (L12, L15 and L26) were re-occupied with a view to trace the dispersal of flood sediment. Indeed, ${ }^{7} \mathrm{Be}$ was detected at the sediment surface of sites L12 and L15 (Fig. 10). This, in conjunction with ${ }^{210} \mathrm{~Pb}$ profiles in these cores, indicates the presence of a freshly deposited flood layer above the flood layer caused by typhoon Haitang one year ago (see the supplemental material archived at the website: http://dmc.earth.sinica.edu. tw/Contributor/Huh/Huh_et_al2007a/). As with the studies off the Eel Shelf (Sommerfield et al., 1999) and the Sepik River (Kineke et al., 2000), our observations suggest divergent pathways for the transport of flood sediments off the KPR: the dominance of gravity-driven flows through the canyon versus surface and subsurface plumes on the adjacent open shelf and slope.

\subsection{A sediment budget in the study area}

An important goal of this study is to calculate a sediment budget with respect to the sediment supplied to the margin from the KPR's drainage basin. The study area includes both conduits (mainly the KPSC) for the transport of sediments toward their ultimate sinks and accommodation space for the local storage of sediments across various timescales. Based on ${ }^{210} \mathrm{~Pb}$-derived sedimentation rates and a finite-element approach, the accumulation flux of sediment was calculated using a framework of 105 triangular grids and covering an area of $3045 \mathrm{~km}^{2}$ (Fig. 11). A mean sedimentation rate is calculated for each grid block by averaging sedimentation rates at the apices of each triangle. Multiplying the area of each triangle by the mean sedimentation rate within it yields the flux of sediment within each grid block. The total flux of sediment from all 105 triangular elements thus calculated is approximately $6.6 \times 10^{6}$ ton/yr (Table 1 ). Of this annual depositional flux, $17 \%$ is distributed on the shelf $(<200 \mathrm{~m})$, $64 \%$ over the slope $(200-1000 \mathrm{~m})$ and $19 \%$ in the basin $(>1000 \mathrm{~m})$. So, much of the narrow $(<20 \mathrm{~km})$ shelf is probably above the level of wave-tide remobilization and unfavorable for sediment accumulation. In comparison, the slope region appears to be a more stable setting for the accommodation of sediments dispersed off the KPR's mouth.

The calculated budget for the shelf-slope-canyon system can only account for $13-18 \%$ of the KPR's annual sediment 


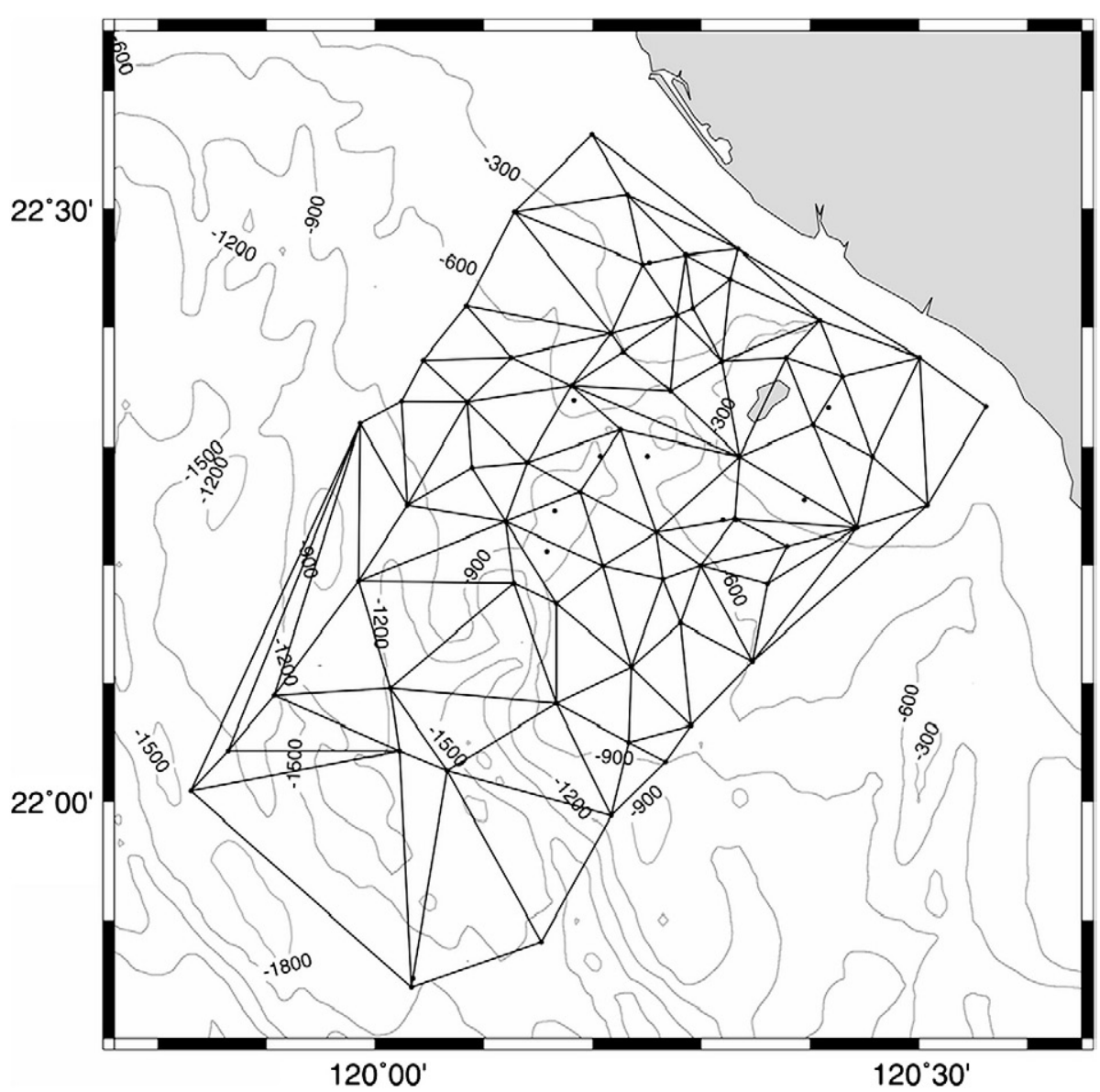

Fig. 11. A framework configured to calculate a sediment budget in the study area. The annual sediment load in the covered area is 6.6 Mton. See text for details.

load, which is reported to be from $36 \mathrm{Mton} / \mathrm{yr}$ (Water Resources Bureau, 1998; Milliman and Kao, 2005) to $49 \mathrm{Mton} / \mathrm{yr}$ (Dadson et al., 2003). The remaining majority (82-87\%) of the river's sediment load may be exported out of the study area by gravity flows through the KPSC. This hypothesis is consistent with efficient sediment dispersal from a small mountainous river off an active collision margin with a narrow shelf and a submarine canyon extending almost into the river's mouth (Milliman and Syvitski, 1992).

Table 1

Sediment budget divided into four bathymetric units in the study area

\begin{tabular}{|c|c|c|c|}
\hline Depth region & $\begin{array}{l}\text { Area } \\
\left(\mathrm{km}^{2}\right)\end{array}$ & $\begin{array}{l}\text { Areal-weighted mass } \\
\text { accumulation rate } \\
\left(\mathrm{g} \mathrm{cm}^{-2} \mathrm{yr}^{-1}\right)\end{array}$ & 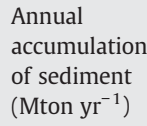 \\
\hline Shelf $(<200 \mathrm{~m})$ & 488 & 0.23 & 1.11 \\
\hline Upper slope (200-600 m) & 567 & 0.44 & 2.49 \\
\hline Lower slope (600-1000 m) & 780 & 0.22 & 1.72 \\
\hline $\operatorname{Basin}(>1000 \mathrm{~m})$ & 1210 & 0.10 & 1.26 \\
\hline Total & 3045 & 0.22 & 6.58 \\
\hline
\end{tabular}

\section{Conclusions}

Based on the distribution of fallout radionuclides in ninetytwo box cores collected during 2004-2006 from an area of $\sim 3000 \mathrm{~km}^{2}$ off the Gaoping River's mouth in SW Taiwan, sedimentation rates and processes are studied. A sediment budget is calculated and compared with the river's annual discharge to elucidate pathways and processes of sediment dispersal and deposition. Detailed analyses of the profiles and the calculated budget lead us to the following conclusions:

(1) Except along the Gaoping Submarine Canyon and the inner shelf region, sedimentation in much of the study area is controlled mainly by steady settling of suspended particles down the water column. Sedimentation rates derived from downcore distribution of ${ }^{210} \mathrm{~Pb}$ using a steady-state model and constrained by ${ }^{137} \mathrm{Cs}$ vary from $<0.1 \mathrm{~cm} / \mathrm{yr}$ in the deep basin to $>1 \mathrm{~cm} / \mathrm{yr}$ in a depositional lobe flanking the canyon at the upper slope region.

(2) From the distribution of sedimentation rates in the study area, we calculate a spatially weighted mean mass accumulation rate of $0.22 \mathrm{~g} \mathrm{~cm}^{-2} \mathrm{yr}^{-1}$, and thus a sediment burial flux of $6.6 \mathrm{Mton} / \mathrm{yr}$ in an area of 
$\sim 3000 \mathrm{~km}^{2}$. This budget can account for no more than $20 \%$ of Gaoping River's annual load, suggesting that the remaining majority of the sediment is most likely exported out of the system via the Gaoping Submarine Canyon.

(3) The extremely intense rainfall in the KPR's drainage basin induced by super-typhoon Haitang during July 18-20, 2005 resulted in an extensive flood layer in the study area. The distribution of this flood layer coincides with the depocenter deduced from ${ }^{210} \mathrm{~Pb}$ chronology. The correspondence suggests that the processes creating event layers may be relevant to the formation of the sediment strata over time scales of 100 years or longer.

(4) The presence of ${ }^{7} \mathrm{Be}$ coupled with low levels and nonsteady-state distribution of ${ }^{210} \mathrm{~Pb}$ in sediments along the canyon floor point to rapid transport of fluvial sediments through the canyon, probably by gravitydriven turbidity flows.

\section{Acknowledgements}

We are thankful to Y.-M. Chen, L.-J. Shiao, C.-T. Hsieh, J.-Y. Chu, J.-Y. Cheng and H.-J. Kao for assistance at sea and/or in the laboratory. The manuscript is improved by critical and constructive reviews from two anonymous reviewers. This work is supported by National Science Council Grants NSC942611-M-001-003 and 95-SR-M-001-002.

\section{References}

Bentley, S.L., Nittrouer, C.A., 2003. Emplacement, modification, and preservation of event strata on a flood-dominated continental shelf: Eel shelf, Northern California. Cont. Shelf Res. 23, 1465-1493.

Brown, W.M. and Ritter, J.R., 1971. Sediment transport and turbidity in the Eel River Basin, California, U.S. Geol. Surv. Water Supply Pap. 1986, 70pp.

Chappell, J., 1993. Contrasting Holocene sedimentary geologies of lower Daly River, northern Australia, and lower Sepik-Ramu, Papua New Guinea. Sediment. Geol. 83, 339-358.

Crockett, J.S., Nittrouer, C.A., 2004. The sandy inner shelf as a repository for muddy sediment: an example from Northern California. Cont. Shelf Res. 24, 55-73.
Dadson, S.J., Hovius, N., Chen, Y.G., Dade, W.B., Hsieh, M.-L., Wilett, S.D., Hu, J.-C., 2003. Links between erosion, runoff variability and seismicity in the Taiwan orogen. Nature 426, 648-651.

Kineke, G.C., Woolfe, K.J., Kuehl, S.A., Milliman, J.D., Dellapenna, T.M., Purdon, R.G., 2000. Sediment export from the Sepik River, Papue New Guinea: evidence for a divergent sediment plume. Cont. Shelf Res. 20, 2239-2266.

Lewis, K.B., Barnes, P.M., 1999. Kaikoura Canyon, New Zealand: active conduit from near-shore sediment zones to trench-axis channel. Mar. Geol. 162, 39-69.

Li, F.-C., Angelier, J., Chen, R.-F., Hsieh, H.-M., Deffontaines, B., Luo, C.-R., Wu, T.-T., Lin, M.-C., 2005. Estimates of present-day erosion on sediment transport in rivers: a case study in Taiwan. C. R. Geoscience 337, 1131-1139.

Liu, J.-T., Liu, K.-J., Huang, J.-C., 2002. The influence of a submarine canyon on river sediment dispersal and inner shelf sediment movements: a perspective from grain-size distributions. Mar. Geol. 181 (4), 357-386.

Milliman, J.D., 1995. Sediment discharge to the ocean from small mountainous rivers: the New Guinea example. Geo-Mar. Lett. 15, 127-133.

Milliman, J.D., Syvitski, J.P.M., 1992. Geomorphic/tectonic control of sediment discharge to the ocean: the importance of small mountainous rivers. J. Geol. 100, 525-544.

Milliman, J.D., Kao, S.-J., 2005. Hyperpycnal discharge of fluvial sediment to the ocean: impact of super-typhoon Herb (1996) on Taiwanese Rivers. J. Geol. 113, 503-516.

Moralles, J., Amaud, M., Radakovitch, O., Marion, C., Cagnat, X., 2006. Radionuclide deposition in the Rhône Riber Prodelta (NW Mediterraneab sea) in response to the December 2003 extreme flood. Mar. Geol. 234, 179-189.

Mullenbach, B.L., Nittrouer, C.A., Puig, P., Orange, D.L., 2004. Sediment deposition in a modern submarine canyon: Eel Canyon, Northern California. Mar. Geol. 211, 101-119.

Sommerfield, C.K., Nittrouer, C.A., 1999. Modern accumulation rates and a sediment budget for the Eel shelf: a flood-dominated depositional environment. Mar. Geol. 154, 227-241.

Sommerfield, C.K., Nittrouer, C.A., Alexander, C.R., 1999. ${ }^{7}$ Be as a tracer of flood sedimentation on the northern California continental margin. Cont. Shelf Res. 19, 335-361.

Syvitski, J.P., Morehead, M.D., 1999. Estimating river-sediment discharge to the ocean: application to the Eel margin, Northern California. Mar. Geol. 154, 13-28.

Yu, H.-S., Chiang, C.-S., Shen, S.-M., 2009. Tectonically active sediment dispersal system in SW Taiwan margin with emphasis on the Gaoping (Kaoping) submarine canyon. J. Mar. Syst. 76, 369-382 (this issue).

Walsh, J.P., Nittrouer, C.A., 2003. Contrasting styles of off-shelf sediment accumulation in New Guinea. Mar. Geol. 196, 105-125.

Water Resources Bureau, 1998. Hydrological Year Book of Taiwan, Republic of China, 1997. Ministry of Economic Affairs, R.O.C. 378 pp.

Woolfe, K.J., Larcombe, P., Naish, T., Purdpn, R.G., 1998. Lowstand rivers need not incise the shelf: an example from the Greater Barrier Reef, Australia, with implications for sequence stratigraphic models. Geology 26, 75-78. 